Patrick Bieler, Jörg Niewöhner

\title{
Universal Biology, Local Society? Notes from Anthropology
}

2018 | Chapter in an Edited Volume | Accepted Manuscript (Postprint)

available at https://doi.org/10.18452/23439

Final version published as:

Patrick Bieler, Jörg Niewöhner: "Universal Biology, Local Society? Notes from Anthropology". In: The Palgrave Handbook of Biology and Society. Edited by Maurizio Meloni, John Cromby, Des Fitzgerald, Stephanie Lloyd. London: Palgrave Macmillan, 2018, pages 641-662. DOI: 10.1057/978-1-137-52879-7_27

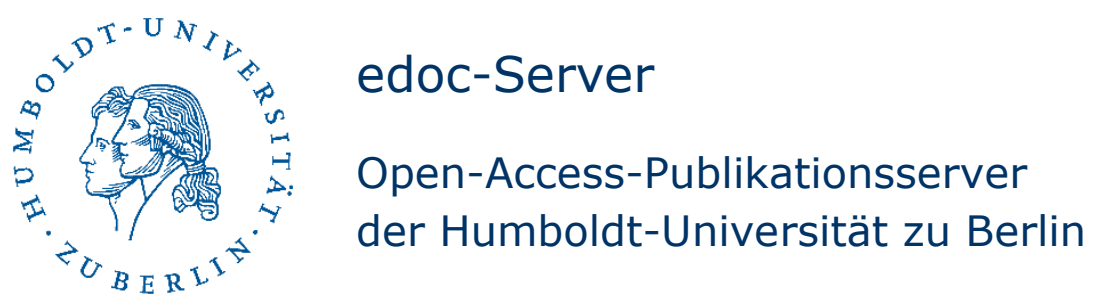




\section{UNIVERSAL BIOLOGY, LOCAL SOCIETY? NOTES FROM ANTHROPOLOGY \\ Patrick Bieler, Jörg Niewöhner}

\section{Introduction}

"City living and urban upbringing affect neural social stress processing in humans" write German psychiatrist Andreas Meyer-Lindenberg and members of his group in a letter to Nature (Lederbogen et al. 2011, 498). On the basis of functional magnetic resonance imaging (fMRI) of cognitive performance under social stress, they argue that birth and early life in cities has a negative effect on stress response dissociable in adulthood, namely a slower operation of the amygdala control circuit in the brain. In a further study, the same group shows significant correlations between exposure to social stress and mental health problems such as schizophrenia (Lederbogen, Haddad and Meyer-Lindenberg 2013).

It is studies like these that over the last 15 years or so have begun to problematize the relationship of biology and society in a new way. In a somewhat ironic turn of events, the search for the essential building blocks of human life in the genome and in the brain returns the result that the molecular and cellular levels of analysis are full of references to 'the social'. It turns out that it is not simply matter "all the way down" (Haraway 2008, 32). Inadvertently, the life sciences are not only showing that the material basis of human biology is already heavily impregnated with remnants of culture understood as practice. They are indeed throwing up findings that question the entire conceptual model of a material base with layers of social practice and cultural values draped over it. In their confusion and indignation, the life sciences recognize that their object of research exceeds what their methods can see. They turn to the social sciences for help so that these may deliver empirical data about 'the social' to a realist understanding of the human body (Nature 2012). In 2016, this is not working all that well. 
At the same time, however, in a further, even more ironic turn, the social sciences have returned from their journey to radical social constructivism and are fully engulfed in discussions about new materialisms (Law and Mol 1995, Barad 1999, Dolphijn and Tuin 2012, Latour 1993). A good time to respond to the cries for help from the life sciences one would think. Yet this is not the case. Social sciences remain wary of biology. For too long, biology, and the human and life sciences more generally, have been (considered) the enemy of critical thought (Tsing 2000). Most domains of cultural and social anthropology - after all part of a discipline with a strong commitment to the scholarly understanding of humankind in all its aspects ("What is Anthropology?" 2016) - still do not show an interest in engaging in discussions about the nature of the human body and indeed the nature of human nature itself (Kuper and Marks 2011). The material dimensions of the human body have been black boxed in most anthropological research and theory due to commitments to critical and social constructivist thinking considered incommensurable with collaborative leanings towards the life sciences (Blackman 2008, Palsson 2016b). Now, the social sciences are beginning to admit materiality into social inquiry and they are considering the role of the human body in social theory. Yet they remain curiously skeptical of the fact that a person is also an organism (Ingold 2000).

This chapter addresses this skepticism. We are aware of the complicated history that exists between biology and society (Meloni 2016, Meloni, Williams and Martin 2016) and that is portrayed so lucidly in many of its facets in this volume. And we are aware of the important social science critique of biology (Foucault 1970). Yet as sociocultural and medical anthropologists we are not entirely happy with the ways the important and multi-facetted relationship between the human material body and social practices is currently being explored. Pragmatic reductionism in the life sciences (Beck and Niewöhner 2006) does not engage generatively with constructivism in the social sciences and vice versa. This is problematic in at least two ways. Firstly, the life sciences are colonizing concepts such as 
'social environment' that have long histories in the social sciences (cf. Landecker and Panofsky in this volume\#). Secondly, if social (science) theory acknowledges the fact that the (re)production of material-semiotic practices involves material agency in some shape or form, it seems imprudent not to engage with biology as a discipline that knows an awful lot about the human material body and material dynamics (Rose 2013, Thrift 2008).

We suggest in this chapter that ethnography is a good way of forging a generative relationship between biology, the human material body, social practices (society) and the social sciences. Ethnography is a relational and humble practice that is happy to stay away from the grand questions of ontology and phenomenology and instead explores the partial connections between matter and meaning in an epistemo-, onto- and phenomenographic mode (Holbraad 2012, Lynch 2013, Niewöhner et al. 2016). Following the ideas of an anthropology of the contemporary (Rabinow 2008, Rabinow et al. 2008), we want to understand the human sciences as forms of practice, which play a central role in shaping the concrete sets of practices within which 'being human' is being done. We think that ethnography carries the potential to produce reflexivity within the epistemic, social and material architectures of late modernities (Law 1994, Boyer 2014). And we suggest that a human body-in-action might work as a boundary object between biological and social scientific research practices (Star and Griesemer 1989).

To argue our case, we revisit four scenes of ethnographic engagement with the intersections of biology and social science from medical anthropology and science and technology studies. We do so by focusing in an exemplary manner on a number of prominent figures in the respective research fields knowing full-well that the fields themselves are much broader and much more heterogeneous than we are able to portray them here. We draw out the role of the material body in each analysis before returning to the case of the relation of mental illness and urban life to outline what we think an ethnographic engagement between biology and society today might sensibly consider of analytical importance. We do not develop a holistic 
argument or resolve questions of nature-culture, human variation or particularity vs. universality. Neither do we mean to suggest a chronology or evolution of inquiry towards some kind of more comprehensive analysis. On the contrary, ours is an attempt to keep the coevalness of analytical approaches and their tensions and their messiness alive in discussions in the natural and social sciences through constant ethnographic engagement that is selfreflexively aware of its strengths and limits. Rather than defining how to 'think' the body as material-discursive assemblage (Blackman 2007), we propose a set of research practices that we want to engage ethnographically through modest withness (Sørensen 2009) in the life scientific vectors of truth claims that are cutting peoples/humans lives in significant ways (Rabinow et al. 2008).

\section{The ethnography of the body as narrated}

In the 1970 s and 1980s a conceptualization of medical encounters as meaningful, mostly language-based communicative processes has become a dominant strand of medical anthropology. Drawing on cross-cultural empirical studies, anthropologists criticized the biological reductionism and universalism of Western medical practice as well as empiricist versions of ethnomedicine. The social dimension of suffering is emphasized and a heuristic distinction between disease, illness and sickness is introduced for analytical purposes (Eisenberg 1977). Whereas disease is understood as only referring to abnormalities of physical functions of the body and thus belonging to the domain of Western biomedical models, illness and sickness are conceptualized as being culturally shaped. According to Kleinman, "[i]llness is the lived experience of monitoring bodily processes" (Kleinman 1988, 3-4) leading people to seek treatment.

Most authors who follow this narrative are interested in how illness is associated with heterogeneous meanings in a particular cultural setting relating to "the metaphors associated with a disease, the ethnomedical theories, the basic values and conceptual forms, and the care 
patterns that shape the experience of the illness and the social relations to the sufferer in a given society" (Good and Good 1981, 176). The main concern is to understand how the meanings of symptoms function as expressions of cultural beliefs and social interactions (Good 1977), how causes and courses of illness episodes are (differently) explained by healers, patients and their social environment (Kleinman 1980, Blumhagen 1980) and how narrating establishes a certain kind of coherence to a person's suffering (Kleinman 1988). Illness is thus personal and interpersonal at the same time. It directs the focus of analysis to individual biographies, family dynamics, the community of the sick person and the interaction of patient and medical professional/healer.

The overall aim is to establish models that can be used by clinicians in order to self-critically reflect their own assumptions, better interpret their patients' symptoms and complaints and deal with the social aspects of their patients' suffering (Kleinman 1981, Good 1995, Mattingly 1991). To the medical anthropologists the illness narratives are both an analytical tool for understanding patients and an important part of the healing process, which can lead to a different perception of the disease opening up possible decisions, actions and futures (Mattingly 2009).

Medical anthropology thus argues for the importance of social and cultural analysis and contextualization of any medically relevant phenomenon instead of reducing it to a physical process. Opposing a universalizing biomedical model, the particularity of the (individual) illness experience is emphasized. Importantly, this particularization emanates from social structure, symbolic webs of meaning and cultural practices. These are rendered as the anthropologists' field of inquiry and expertise (Kleinman and Kleinman 1991). Medical outcomes are of interest to the practitioner Kleinman and other scholars who argue for engaging with medical practitioners (Mattingly 1991). However, as the focus of these analyses is clearly to argue against biomedical reductionism with a primary focus on disease (Hahn and Kleinman 1983), the material body is almost framed as the universal carrier of 
cultural variation. It is an asymmetrical perspective that locates agency in culture, rendering the material body somewhat inert.

A changing medical anthropology in the 1980s driven by historical epistemological concerns about the contingent nature of knowledge practices, by matters of political economy and by feminist critique, begins to consider this perspective too individualistic and too narrowly focused on the patient-healer interactions (Young 1982). The strong reliance upon language is also criticized for assuming rational actors (Young 1981). According to Young, the medical system itself is always already socially and historically contingent and should, in effect, be understood as a set of situated practices. Thus, Young argues in favor of a critical reflection of the processes of knowledge production (in terms of power hierarchies) and its social effects (differential access to the medical system as a result of social inequality). Furthermore, he suggests the study of different forms of medical knowledge in their everyday use in order to account for the complex and sometimes contradictory statements of patients. What emerges from these early contributions is a new critical medical anthropology that necessitates an anthropology of biomedicine. Illness narratives are shaped as much by social structures as they interact with processes of knowledge production. The latter processes are no longer seen as a homogeneous body of medical knowledge, but rather empirically and analytically pried open to reveal a heterogeneous set of knowledge and healing practices deeply enmeshed with matters of political economy and systems of (biopolitical) governance. The relationship between biology (as a discipline) and society is increasingly investigated in a constructivist and post-structuralist vocabulary that the interaction between science and technology studies, feminist critique and cultural anthropology has brought forth. In this vein, ethnographic research is increasingly conducted within the engines of discovery, production and circulation of medical knowledge primarily in Euro-America (Hacking 2007, Lock and Nguyen 2010). The material body becomes an object of power/knowledge practices and a site of biopolitics. 


\section{The ethnography of the body as known}

Early critical medical anthropology studied illness and healing in faraway settings. Yet, at the same time as Euro-American anthropologists travelled abroad, their own, 'modern healing systems' radically changed after World War II - and so did the relationship of biology and society. The health care sector grew dramatically through huge state investments in private and public institutions. Medical knowledge production and clinical interventions became more widespread and more powerful. The term medicalization was established in order to describe medicine's expansive tendencies replacing and complementing legal jurisdiction and becoming increasingly implicated in peoples' everyday lives (Zola 1972). Illness and disease were theorized as products of social interaction posing the question how people come to accept and participate in medical institutions. Not only did the reach of medicine expand, medicine itself changed quite dramatically. From the mid-1980s onwards, technologically enabled scientific innovations have rapidly changed the organization and practices of biomedicine. Clarke and others have termed this the 'era of biomedicalization', characterized by the inseparability of technological innovations and scientific knowledge production (Clarke et al. 2003). Medicine, health and illness are increasingly economized.

Biomedicine's pervasiveness in modern societies, its embeddedness within political economy and its role in shaping modes of governance, rapidly attracted critical attention from the social sciences and philosophy. Most prominently, of course, Michel Foucault demonstrated in his lectures on biopolitics how medicine has introduced a new episteme into modern society that significantly shapes the conditions of possibility for subjectivity and sociality (Foucault and Faubion 2000). Two major strands of empirical investigation operate within this framework of biopolitics that need to be considered in more detail: On the one hand, a focus on the discourse of genetic risk emphasizes its highly individualizing effects and the ethical implications of constant responsibility for one's own individual health (Novas and Rose 2000, Rose 2001); on the other hand, authors emphasize the changes of individual and collective 
identification processes along new and widely distributed knowledge(s) of the biological body (Rabinow 1992) and its potentialities for political claims (Petryna 2003). These strands provide an epochal analysis of how technologically assisted biological knowledge production (especially in the field of genetics) shapes and changes 'modern' understandings of human bodies and being human (Franklin 2003).

For sociologist Nikolas Rose, the current discourse surrounding genetics leads to the identification of individual risk susceptibilities on the molecular level with the intention to prevent disease and illness. Although Rose argues that this is not a new mechanism of social control and power relations, he identifies a new mode of practicing biopolitics which he calls ethopolitics: "By ethopolitics I mean to characterize ways in which the ethos of human existence - the sentiments, moral nature or guiding beliefs of persons, groups or institutions have come to provide the 'medium' within which the self-government of the autonomous individual can be connected up with the imperatives of good government. [...] If discipline individualizes and normalizes, and biopower collectivizes and socializes, ethopolitics concerns itself with the self-techniques by which human beings should judge themselves and act upon themselves to make themselves better than they are." (Rose 2001, 18) This new form of politics does not operate on the level of coercion, but rather through individual choice and the idea of optimizing individual lives, which, in turn, creates an individual responsibility for one's own biological and psychological resilience. Biomedical practices are thus construed to provide knowledge individuals can turn on themselves. However, as Rose also suggests, biopolitical knowledge production relies on technological innovation and thus depends on a biological industry. Biopolitics as ethopolitics is at the same time also bioeconomics and the "politics of life itself" is at least partially controlled by those actors with financial resources. The human material body known through biology is in many ways at the heart of this critical social inquiry. It is conceptualized as a site of politics involving state and economic agents, medical practitioners and scientists as well as individuals performing technologies of the self. 
Yet analytical attention lies on and stays with the biopolitical and -economic processes that provide the basis for knowing and regulating the body. How this affects the human material body is of lesser concern.

In introducing the term biosociality in the early 1990s, anthropologist Paul Rabinow has lead the way for a related argument which shifts the focus onto a different facet of biopolitics. Rabinow is interested in the emergence of new collective identities referring to the genetic knowledge(s) made available to the public at large. In a sharp critique of socio-biology (Wilson 1975), i.e. the biological explanation of (social) behavior and social structure, Rabinow analyses how the new biomedical practices (especially of genetics) change the configuration of social domains along biological lines, which are themselves the effects of the entanglements of knowledge production and collective action: "If sociobiology is culture constructed on the basis of a metaphor of nature, then in biosociality nature will be modeled on culture understood as practice." (Rabinow 1992, 241). This process is highly dependent on technological innovation and scientific classification systems as the material basis for the identification of self and other according to genetic properties. The affected actors are not passive objects of this trend. Rather, knowing their biological body provides a means for collective action. Thus, the possibility is opened for claiming rights and (self-) representation according to the known materiality of the body. This is captured in the terminology of biological citizenship (Petryna 2003, Novas and Rose 2000). The emergence of biosocial identities can call for political action among different actors - affected and non-affected alike - and have an effect on the practices of medical knowledge production and classification (Epstein 2007). Hence, biomedical knowledge(s) and biosocial identification are coconstitutive.

The (bio)medical critique and the specific versions of biopolitics enable an analysis of how biological knowledge shapes society through discourse. In line with Foucault, the material body is first and foremost accessible through knowledge, which is itself bound to its epoch. 
The known body is a major resource for processes of identification shaping individual and collective experience, self-knowledge and identity, offering subject positions and legitimating rights claims. However, the transformations of the material body as effects of these practices and discourses over time and through different milieus receive little empirical attention.

\section{The ethnography of the body as lived}

In the 1980 s, it is feminist critique gaining ground within public discourse and beginning to enter the academy and particularly anthropology that starts to explicate the central role of the material body for social inquiry. Particularly female anthropologists are developing an explicit concern for the human body. This comprises three levels of analysis: the individual body "understood in the phenomenological sense of the lived experience of the body-self"; the social body "referring to the representational uses of the body as natural symbol with which to think about nature, society and culture"; and the body politic, "referring to the regulation, surveillance, and control of bodies (individual and collective) in reproduction and sexuality, in work and leisure, in sickness and other forms of deviance and human difference" (Scheper-Hughes and Lock 1987, 7-8). This agenda is gaining immense traction. While particularly the body politic dimension is investigated discursively at macro levels as a matter of life itself and biopolitics (see above), ethnographic and anthropological work also focuses on life as such (Fassin 2009). This shifts the level of analysis to the domain of everyday life. The focus of attention is on the role of the body and biomedical institutions in rendering life meaningful and bearable. Much like Kleinman, illness experience is understood to be closely connected with the healing system. While Kleinman conducted his work within non-Western groups and societies, feminism and science and technology studies carry this agenda into the heart of Euro-American biomedicine. Yet where the ethnography of biopolitical processes focused primarily on sites of knowledge production and medical treatment, this new critical medical anthropology analyses 'living and working with the new medical technologies' 
(Lock, Young and Cambrosio 2000). It investigates the emergent biomedical practices and their inherent logics in themselves, their embeddedness within other social and ethical formations as well as their consequences for people whose everyday lives are being cut by these new vectors of truth claims (Martin 1994, Rapp 2004, Konrad 2005). These studies contribute detailed ethnographic material on healing systems and how they shape individual and collective illness and bodily experience. They also lead to a whole series of studies of the diversity of the material body as subject of biomedical (self)knowledge (Lock and Farquhar 2007). While they harbor a deep-seated skepticism towards biology and biomedicine, their ethnographic exposure to clinical and research routines lets them experience the heterogeneity of biomedicine in practice. Consequently, these anthropological approaches problematize the biological and medical(ized) body as lived and situated within diverse and often vernacular social, ethical and epistemic practices.

\section{The ethnography of the body as practiced}

Empirical research of biomedicine in practice is also carried out by Dutch empirical philosopher Annemarie Mol (Mol 2002, Mol and Law 2004). While a child of constructivism, her interest does not so much lie with understanding how social configurations and individual experiences of the body are shaped and changed by biomedical practices and interventions. Stemming mostly from fieldwork on atherosclerosis in a medical clinic, Mol instead develops an ontological argument arguing for a multiplicity of the human body in practice: The human body exists only as and when enacted within practice (Mol 2002). Thus, what the body (disease) is depends entirely on how the body (disease) is done at any given moment. According to Mol, this does not mean that the body is fragmentary: Quite the contrary, her concept of the body multiple emphasizes that although the human body (disease) is done always partially in different practices, it is at the same time coordinated into a whole through the combination of clinical practice and medical knowledge. In Mol's analysis the materiality 
of the human body and its ability for resistance is captured as she conceptualizes the observed practices as material-semiotic. Materiality is present in co-producing the body.

Mol's framework is the attempt to ethnographically account for a body which is real and (socially) constructed at the same time. The radical emphasis on practice as the unit of analysis is an ontological argument against the idea of a universal body that is only epistemologically particularized - this is still implicit in the approaches of the experienced and known body. The (materiality of the) body is only accessible through epistemic practices. The perspective questions the separation of inside/outside, nature/culture and subject/object and constructs the body as an amalgam of heterogeneous co-producing human and nonhuman elements which is never finished, but in a constant process of becoming. Finally, to distinguish clearly between the biological and social dimensions of human life is no longer possible from this perspective. This does not mean, however, that they are one and the same, either. Yet, the radical practice oriented approach of enactment is clearly focused on the processes of doing the body in medical practice. This is not a particular blind spot as the argument is not in itself anthropological. Nevertheless, ethnographically examining the material consequences of doing the body should be of interest to anthropologists, we argue, as questions of human development and evolution are in the focus of the discipline's matters of concern (Marks 2013).

Explicitly dealing with this interest is Margaret Lock's concept of local biologies, which develops a cultural anthropological concern for the material body. Although it can probably not solve the questions raised, it is especially interesting because it is not a theoretical concept that tries to explain the relation of nature and culture in producing a particular biological body and its social experience. Rather, it is an ethnographic notion that insists on the historical, social and political situatedness of the co-constitution of material and social phenomena. The notion of local biologies suggests a materialism of lived bodies (Lock and Farquhar 2007) that 
does not start from nature/culture and subject/object dichotomies, but rather starts from the situated practices of doing, experiencing and knowing the body.

"[L]ocal biologies refers to the way in which the embodied experience of physical sensations, including those of well-being, health, illness, and so on, is in part informed by the material body, itself contingent on evolutionary, environmental, and individual variables. Embodiment is also constituted by the way in which self and others represent the body, drawing on local categories of knowledge and experience. If embodiment is to be made social, then history, politics, language, and local knowledge, including scientific knowledge to the extent that it is available, must inevitably be implicated. This means in practice that, inevitably, knowledge about biology is informed by the social, and the social is in turn informed by the reality of the material. In other words, the biological and the social are coproduced and dialectically reproduced, and the primary site where this engagement takes place is the subjectively experienced, socialized body. The material body cannot stand, as has so often been the case, as an entity that is black-boxed and assumed to be universal, with so much sociocultural flotsam layered over it. The material and the social are both contingent - both local." (Lock 2001, 483-84)

This concept has been informed by Lock's long-term ethnographic work in Japan (Lock 1993). Lock noticed striking differences in the way 'menopause' was experienced by Japanese women compared to women in North America; most obvious, perhaps, the absence of 'hot flashes' as a symptom of hormonal changes so regularly reported by North American women. Rather than reducing this differential experience to either culture (different discourse) or nature (different bodies), Lock weaves a thick ethnographic narrative that draws together differences in media reporting and public discourse, women's accounts of experiences, body images and genealogies of 'aging' narratives within a broader analysis of cultural and political context, including the role of the medical system. The result is not so much an 
explanation of cross-cultural differences in individual bodily experience, but rather an ethnographic account of the diversity and contingency of female aging.

Importantly in this context, this is not a cultural anthropological account of the political, discursive and symbolic variance above a real and universal biological body. Neither is the account ignorant of a biological body. While Lock is a socio-cultural anthropologist with a degree of biological training, she has connected biological anthropological expertise to her ethnographic perspective. The role of soy as a major component of the Japanese diet has been shown to influence the levels of flavonoids in the body, which act as phytoestrogens on the body's hormone system (Melby 2005, 2015, Melby, Lock and Kaufert 2005). So the differences in symptom reporting appear to have a biological aspect. In fact, the body becomes materially situated through particular food cultures.

Yet the concept of local biologies is neither interested in grounding social experience in a presocial material body (Raman and Tutton 2010), nor is it interested in taking these biological accounts of the material body as reified truths. Rather local biologies insists on investigating the experienced body as a site of epistemic, social, historical and political contestation. In this sense, it is firmly rooted within the social constructivism of the 1970s. Yet the experienced body is also a site of material contestation and knowledge about and experience of the material body is always situated (Haraway 1988). Thus, Lock's interest in the materialism of lived bodies starts from the situated practices of doing, experiencing and knowing the body.

\section{An example: Mental illness in the city}

In the previous sections we have traced the strengths of ethnographic research at the interface of the human material body, biology, medicine and society. Admittedly, we have been selective and have only sketched the different approaches as heuristic markers to make our case for an ethnographic engagement of anthropology (social science) and biology. We apologize to specialists in any of these areas for eviscerating what is so dear to them and we 
refer non-specialist readers to the multitude of volumes on the various facets of the subject (see especially Lock and Farquhar 2007). Our case, however, remains firm: The material body plays an important role in societal matters of difference and deviance. We need to stick with the lived body through practices; we need to take into account its experiences, its 'use' by a person, need to understand how it is known and how this knowledge is situated historically and socially. We need to understand how it is done in practices and how being done in certain ways affects the way subjects, socialities and societies construe themselves.

What we aim to achieve is to open up and engage in a debate on how to ethnographically grasp and account for human (group) life without privileging cultural or biological explanations.

To conclude, we return to the beginning of this chapter and discuss the case of mental illness in cities to outline the different dimensions through which the material body can enter an ethnographic analysis of the case. Taking this specific relation to the center of analysis has two reasons: firstly, today more than half of the world's population lives in cities. This trend will rapidly increase within the next decades and the design of "healthy urban environments" is becoming a central paradigm for urban governance. Even more importantly, specific subdisciplines of biological and epidemiological research have rediscovered the field of mental health in cities and thereby undergone an epistemological shift, while at the same time this topic has a long tradition in ecological thinking within the social sciences (Fitzgerald, Rose and Singh 2016b). Anthropological research (especially in medical anthropology and the broad field of science studies) has not explicitly dealt with these questions so far, but, as we have argued, provides different useful tools for a better empirical understanding of the materiality of the body in a globalized, yet locally practiced world. We will therefore end with four propositions for anthropological research on mental health in cities.

\subsection{Staying with the body through ecologies of practice}


We argue that the conceptualization of the body as being done in practices focusing on medical encounters in clinics can and should be translated into the urban environment. The body-in-action is thus constantly done through its embeddedness in the urban. Taking Mol's account into the city emphasizes the socio-material dimensions of mental health as concrete, observable doings. Even more, Mol's ontological conception of the body is crucial because it is completely different from most psychiatric/neuroscientific conceptualizations. Mental disease is thus not a separated essence from its surrounding environment, but constantly enacted within shifting urban cosmopolitics (Blok and Farías 2016). Participant observation in the everyday movements of people diagnosed as mentally ill in the city could point to the centrality of lived space, paying attention to the various trajectories that built environments afford for people with psychiatric symptoms as well as the dynamics of social interactions in the city, while at the same time understanding the urban environment not as stable, but as (different) 'niches' which are co-constituted through the bodily practices (Bister, Klausner and Niewöhner 2016). This perspective enables us to think "how bodies are permeated through atmospheres and environments" (Fitzgerald, Rose and Singh 2016a, 233). The bodyin-action implies that it must be ethnographically accounted for in its complex entanglements with the assembled environment instead of trying to measure clearly defined, decontextualized variables (Söderström 2017). It is thus a useful tool for altering the status of the biological body (see 6.4).

As we are especially interested in thinking with the material consequences of the processes of how the body is done, situated biological knowledge about the different influences of specific environments on brain functions and their long-term effects on human development and phenotypes should be acknowledged (Timmermans and Haas 2008) and tried to be included into anthropological conceptions of human-environment relations (Ingold and Palsson 2013). There is not a straightforward strategy how to include these findings into ethnographic research. Correlations of social and material environments with neurobiological or 
(epi)genetic patterns or markers do not readily relate to thick narratives or add up to some kind of comprehensive account (Downey 2016). Yet putting these accounts next to each other and reading them relationally might produce something interesting and offers the chance to enrich the life sciences as well as the social sciences.

\subsection{Locating the body differently through a biographical perspective}

As we commit ourselves to thinking about the material consequences of living in cities, we are further suggesting a long-term biographical perspective on the experienced body as an object of ethnographic research. The phenomenological approaches in medical anthropology as well as the concept of local biologies emphasize that experience is not given a-priori, grounded in the biological materiality of the human body, but is (historically) embedded in cultural, social, political and epistemic practices. As we have shown, phenomenological approaches tend to focus on a narrative analysis of illness experiences and explanatory models. We find it crucial in this respect that Margaret Lock's research demonstrates in how far different accounts of symptoms should not be explained simply with reference to cultural differences in the representation of sickness - they might well be grounded in biological differences that result from living the body differently. Thus, we find this perspective to be complementary with the inquiry of the body in ecologies of practice. However, the political and moral dimensions of the materiality of the body are more explicitly dealt with - what we believe Didier Fassin is interested in conceptualizing "life as the course of events which occurs from birth to death, which can be shortened by political or structural violence, which can be prolonged by health and social policies, which gives place to cultural interpretations and moral decisions [...]." (Fassin 2009, 48) Here, the focus of analysis is strongly directed towards the embeddedness of individuals in local ecologies of care over time (Das and Das 2006). Illness narratives and explanatory models can be a starting point for an analysis of the interactions of (1) social positioning, (2) attitudes and behaviors towards mental distress in 
relation to biomedical knowledge production, (3) cultural, social and economic resources, (4) treatment decisions and options, (5) technologies of the self and social moral orders, including specific distributions of shame and blame, (6) social dynamics (e.g. inclusion / exclusion / stigma in families, neighborhoods, etc.) and (7) biosocial identity formation. The role of medical institutions, drug regimen and treatment carriers can be illuminated by trying to reconstruct the 'medical career' of the sick person through documents and interviews with past practitioners and ancestors (Biehl 2005). This can be an extremely laborious task demanding huge personal and ethical commitment from the researchers. However, this perspective is anthropologically useful because it is dynamic and emphasizes change within the life course. It opens up the possibility to research lifestyle-environment-body trajectories (Bowker and Star 1999) or human-milieu-environment relations (Palsson 2016a).

\subsection{Accounting for the body in urban epistemic spaces}

The human body cannot be separated from knowledge and skill. The way people conduct and experience themselves, the way medical institutions operate, the way epistemic cultures of biology contribute to enacting the body multiple, all this is shaped significantly by knowledge practices. That medical knowledge heavily shapes social relations as well as collective and individual identity formation has been made evident through biopolitical critique. Yet the production of difference and deviances within societies has long ceased to be a matter of specialized medical knowledge being received by a lay public. The vectors of truth claims have long started to operate within much more diverse ecologies of expertise involving public and private actors as well as infrastructures, technology, and natural and moral orders (Beck 2015). Knowledge is not just in the mind and affecting technologies of the self. The current neuroscientific domination in psychiatric research begins to approach urban planning (Fitzgerald, Rose and Singh 2016a). The built environment comes under scrutiny from the medical and the molecular gaze (Landecker and Panofsky 2013). Interventions into the 
material world might foreshadow a new kind of pastoral power that does not address itself to human subjects any longer, but that constructs healthy environments that govern subjects at a new kind of distance (Kontopodis, Niewöhner and Beck 2011, Niewöhner 2011). Ethnographic research needs to understand and become involved in these ecologies of expertise in order to understand how matters of fact become matters of concern (Latour 2004) in material, social and cultural contexts. How does this shape and transform urban environments and care infrastructures? What are the effects for people's dwellings (see 6.1)? And how do people's experiences of illness, their treatment decisions and options as well as their social relations develop and change over time (see 6.2)? The notion of ecologies of expertise moreover offers a chance for new forms of collaboration between social science, medicine and people with experiences of psychiatry. This might lead to at least local and experimental transformations of psychiatric classifications (see 6.4).

\subsection{Altering the ontological status of the biological body through co-laboration}

We have outlined the dimensions of the body-in-action that are accessible to ethnography as conventionally understood in anthropology. Yet there might be more to do for ethnographic inquiry. Barry and colleagues point to different modes of interdisciplinary collaboration (Barry and Born 2013). In their agonistic-antagonistic mode of interdisciplinary engagement, one of the partners is trying to change the ontological status of their collaborator's object of research. This resonates with much recent writing about ethnographic projects that co-laborate with (Niewöhner 2016), experimentally entangle (Fitzgerald and Callard 2014, Callard and Fitzgerald 2015), para-sitically attach (Marcus 2010, Deeb and Marcus 2011) or embed (Rabinow and Bennett 2012) the ethnographer in life scientific contexts. We have outlined the body-in-action above and we suggest here that co-laboration between biology and social science - understood as temporary joint epistemic work - might lead to research designs that 
capture this body-in-action as it is lived and used out there, shaped by everyday patterns of practice.

Ever since early enlightenment when moderns started to understand the natural world in terms of laws rather than customs (Daston 2002), biology has been left on the edge of the natural sciences not entirely sure about the epistemological status of the natural order. We have witnessed many universalizing projects, particularly within the recent large-scale genome initiatives. Yet we have also witnessed counter-movements that have focused on emergent embodied phenotypes (Krieger 2013) and emphasized dynamic, ecological and systemic perspectives (Oyama, Griffiths and Gray 2001). The fact that certain subdisciplines within biology and epidemiology have started to open up the discussion on the deep entanglement of body and environment is a valuable entry point for working together on situating biology and differentiation. For social scientists and anthropologists this momentum is a chance to account for the material dimensions of social differentiation - understood not in terms of measurable variables, but as a complex biosocial phenomenon. It is an opportunity to go beyond the idea of situating universal bodies in local contexts and it invites anthropology to empirically translate the theoretical insights of the new materialisms in order to understand in how far and through what practices the materiality of the body is (made) local.

Anthropology should thus neither function in the mode of distant (social constructivist) critique nor as a data delivery machine, which is only appending the 'social context' for natural science research. There is the potential to shift the research methodology and become an epistemic partner that can generate critique from engagement with its co-laboration partners. We see the potential to develop anthropological theory through approaching the materiality of human (group) life in an experimental mode. The body-in-action, we suggest, might work as a boundary object for biology and ethnography. It might produce a somewhat more integrated perspective, yet, more likely, it will produce bodies in both disciplines that 
are good to think with and that help to avoid unnecessarily early slips into reductionisms of one kind or another.

\section{References}

Barad, Karen. 1999. "Agential Realism: Feminist Interventions in Understanding Scientific Practices." In The Science Studies Reader, edited by Mario Biagioli (eds), 1-11. London; New York: Routledge.

Barry, Andrew and Georgina Born (eds). 2013. Interdisciplinarity: Reconfigurations of the Social and Natural Sciences. London; New York: Routledge.

Beck, Stefan. 2015. "The Problem of Expertise: From Experience to Skilful Practices to Expertise. Ecological and Pragmatist Perspectives." European Journal of Pragmatism and American Philosophy 7(1): 8-23.

Beck, Stefan and Jörg Niewöhner. 2006. "Somatographic investigations across levels of complexity." BioSocieties 1(2): 219-27.

Biehl, João 2005. Vita: Life in a Zone of Social Abandonment. Berkeley: University of California Press.

Bister, Milena D., Martina Klausner and Jörg Niewöhner. 2016. "The cosmopolitics of "niching'." In Urban Cosmopolitics: Agencements, Assemblies, Atmospheres, edited by Anders Blok and Ignacio Farías (eds), 187-206. Abingdon, Oxon; New York: Routledge.

Blackman, Lisa. 2007. "Psychiatric Culture and Bodies of Resistance." Body \& Society 13(2): $1-23$.

Blackman, Lisa. 2008. The Body: The Key Concepts. Oxford; New York: Berg.

Blok, Anders and Ignacio Farías (eds). 2016. Urban Cosmopolitics: Agencements, Assemblies, Atmospheres. Abingdon, Oxon; New York: Routledge.

Blumhagen, Dan. 1980. "Hyper-tension: A folk illness with a medical name." Culture, Medicine and Psychiatry 4(3): 197-227.

Bowker, Geoffrey C. and Susan Leigh Star. 1999. Sorting Things Out: Classification and Its Consequences. Cambridge, Massachusetts; London, England: The MIT Press.

Boyer, Dominic. 2014. "Reflexivity Reloaded. From Anthropology of Intellectuals to Critique of Method to Studying Sideways." In Anthropology Now and Next: Essays in Honor of Ulf Hannerz, edited by Thomas Hylland Eriksen, Christina Garsten and Shalini Randeria (eds), 91-110. New York; Oxford: Berghahn.

Callard, Felicity and Des Fitzgerald. 2015. Rethinking Interdisciplinarity across the Social Sciences and Neurosciences. New York: Palgrave Macmillan.

Clarke, Adele E.et al. 2003. "Biomedicalization: Technoscientific transformations of health, illness, and US biomedicine." American Sociological Review 68(2): 161-94.

Das, Veena and Ranendra K. Das. 2006. "Pharmaceuticals in Urban Ecologies: The Register of the Local." In Global Pharmaceuticals: Ethics, Markets, Practices, edited by Adriana Petryna, Andrew Lakoff and Arthur Kleinman (eds), 171-205. Durham; London: Duke University Press.

Daston, Lorraine. 2002. I The Morality of Natural Orders: The Power of Medea \& II. Nature's Customs versus Nature's Laws. In Tanner Lectures on Human Values. Harvard, MA.

Deeb, Hadi Nicholas and George E. Marcus. 2011. "In the Green Room: An Experiment in Ethnographic Method at the WTO." PoLAR: Political and Legal Anthropology Review 34(1): 51-76. 
Dolphijn, Rick and Iris van der Tuin. 2012. "New Materialism: Interviews \& Cartographies." Open Humanities Press. Accessed 20/10/2010. http://www.oapen.org/download?type $=$ document\&docid $=444388$

Downey, Greg. 2016. "Being Human in Cities: Phenotypic Bias from Urban Niche Construction." Current Anthropology 57(S13): S52-S64.

Eisenberg, Leon. 1977. "Disease and illness distinctions between professional and popular ideas of sickness." Culture, Medicine and Psychiatry 1(1): 9-23.

Epstein, Steven. 2007. Inclusion: The Politics of Difference in Medical Research. Chicago: University of Chicago Press.

Fassin, Didier. 2009. "Another Politics of Life is Possible." Theory Culture \& Society 26(5): 44-60.

Fitzgerald, Des and Felicity Callard. 2014. "Social Science and Neuroscience beyond Interdisciplinarity: Experimental Entanglements." Theory, Culture \& Society 32(1): 332.

Fitzgerald, Des, Nikolas Rose and Ilina Singh. 2016a. "Living well in the Neuropolis." The Sociological Review Monographs 64(1): 221-37.

Fitzgerald, Des, Nikolas Rose and Ilina Singh. 2016b. "Revitalizing sociology: urban life and mental illness between history and the present." The British Journal of Sociology 67(1): 138-60.

Foucault, Michel. 1970. The Order of Things: An Archaeology of Human Sciences. New York: Random House.

Foucault, Michel and James D. Faubion. 2000. Power. New York: New Press; Distributed by W.W. Norton.

Franklin, Sarah. 2003. "Re-thinking nature-culture: Anthropology and the new genetics." Anthropological Theory 3(1): 65-85.

Good, Byron J. 1977. "The heart of what's the matter: The semantics of illness in Iran." Culture, Medicine and Psychiatry 1(1): 25-58.

Good, Byron J. and Mary-Jo DelVecchio Good. 1981. "The meaning of symptoms: a cultural hermeneutic model for clinical practice." In The relevance of social science for medicine, edited by Leon Eisenberg and Arthur Kleinman (eds), 165-96. Dordrecht, Boston; Hingham, MA: D. Reidel Pub. Co. .

Good, Mary-Jo DelVecchio. 1995. American Medicine: The Quest for Competence. Berkeley: University of California Press.

Hacking, Ian. 2007. "Kinds of People: Moving Targets." Proceedings of the British Academy 151: 285-318.

Hahn, Robert A. and Arthur Kleinman. 1983. "Biomedical Practice and Anthropological Theory: Frameworks and Directions." Annual Review of Anthropology 12(1): 305-33.

Haraway, Donna. 1988. "Situated knowledges: The science question in feminism and the privilege of partial perspective." Feminist Studies 14(3): 575-99.

Haraway, Donna Jeanne. 2008. When Species Meet. Minneapolis: University of Minnesota Press.

Holbraad, Martin. 2012. Truth in Motion: The Recursive Anthropology of Cuban Divination. Chicago; London: University of Chicago Press.

Ingold, Tim. 2000. The Perception of the Environment: Essays on livelihood, dwelling \& skill. Abingdon, Oxon; New York: Routledge.

Ingold, Tim and Gisli Palsson (eds). 2013. Biosocial Becomings: Integrating Social and Biological Anthropology. Cambridge; New York: Cambridge University Press.

Kleinman, Arthur. 1980. Patients and Healers in the Context of Culture: An Exploration of the Borderland Between Anthropology, Medicine and Psychiatry Berkeley: University of California Press. 
Kleinman, Arthur. 1981. "On illness meanings and clinical interpretation: Not 'rational man', but a rational approach to man the sufferer/man the healer." Culture, Medicine and Psychiatry 5(4): 373-77.

Kleinman, Arthur. 1988. Illness Narratives: Suffering, Healing and the Human Condition. New York: Basic Books.

Kleinman, Arthur and Joan Kleinman. 1991. "Suffering and its professional transformation: toward an ethnography of interpersonal experience." Culture, Medicine and Psychiatry 15(3): 275-75.

Konrad, Monica. 2005. Narrating the New Predictive Genetics: Ethics, Ethnography and Science. Cambridge: Cambridge University Press.

Kontopodis, Michalis, Jörg Niewöhner and Stefan Beck. 2011. "Investigating Emerging Biomedical Practices: Zones of Awkward Engagement on Different Scales." Science, Technology \& Human Values 36(5): 599-615.

Krieger, Nancy. 2013. "History, Biology, and Health Inequities: Emergent Embodied Phenotypes and the Illustrative Case of the Breast Cancer Estrogen Receptor." American Journal of Public Health 103(1): 22-27.

Kuper, Adam and Jonathan Marks. 2011. "Anthropologists unite!" Nature 470: 166-68.

Landecker, Hannah and Aaron Panofsky. 2013. "From Social Structure to Gene Regulation, and Back: A Critical Introduction to Environmental Epigenetics for Sociology." Annual Review of Sociology 39(1): 333-57.

Latour, Bruno. 1993. We Have Never Been Modern. Cambridge, Massachusetts: Harvard University Press.

Latour, Bruno. 2004. "Why Has Critique Run out of Steam? From Matters of Fact to Matters of Concern." Critical Inquiry 30(2): 225-48.

Law, John. 1994. Organizing Modernity: Social Order and Social Theory. Oxford; Cambridge, Massachusetts: Blackwell

Law, John and Annemarie Mol. 1995. "Notes on materiality and sociality." The Sociological Review 43(2): 274-94.

Lederbogen, Florian, Leila Haddad and Andreas Meyer-Lindenberg. 2013. "Urban social stress - Risk factor for mental disorders. The case of schizophrenia." Environmental Pollution 183: 2-6.

Lederbogen, Florianet al. 2011. "City living and urban upbringing affect neural social stress processing in humans." Nature 474: 498-501.

Lock, Margaret. 1993. Encounters with Aging: Mythologies of Menopause in Japan and North America. Berkeley: University of California Press.

Lock, Margaret. 2001. "The Tempering of Medical Anthropology: Troubling Natural Categories." Medical Anthropology Quarterly 15(4): 478-92.

Lock, Margaret and Judith Farquhar (eds). 2007. Beyond the Body Proper: Reading the Anthropology of Material Life Durham: Duke University Press.

Lock, Margaret M., Allan Young and Alberto Cambrosio (eds). 2000. Living and Working with the New Medical Technologies: Intersections of Inquiry. Cambridge: Cambridge University Press.

Lock, Margaret and Vinh-Kim Nguyen. 2010. An Anthropology of Biomedicine. Malden, Massachusetts; Oxford: Wiley-Blackwell.

Lynch, Michael. 2013. "Ontography: Investigating the production of things, deflating ontology." Social Studies of Science 43(3): 444-62.

Marcus, George E. 2010. "Contemporary Fieldwork Aesthetics in Art and Anthropology: Experiments in Collaboration and Intervention." Visual Anthropology 23(4): 263-77.

Marks, Jonathan. 2013. "The Nature/Culture of Genetic Facts." Annual Review of Anthropology 42(1): 247-67. 
Martin, Emily. 1994. flexible Bodies: the role of immunity in American culture from the days of Polio to the age of AIDS. Boston: Beacon Press.

Mattingly, Cheryl. 1991. "The Narrative Nature of Clinical Reasoning." American Journal of Occupational Therapy 45(11): 998-1005.

Mattingly, Cheryl. 2009. "Reading Medicine: Mind, Body, and Meditation in One Interpretive Community." New literary history 37(3): 563-81.

Melby, Melissa K. 2005. "Factor analysis of climacteric symptoms in Japan." Maturitas 52(34): 205-22.

Melby, Melissa K. 2015. "Lessons on aging: Hopes and concerns of Japanese women at midlife." Journal of Women \& Aging 28(2): 1-14.

Melby, Melissa K., Margaret Lock and Patricia Kaufert. 2005. "Culture and symptom reporting at menopause." Human Reproduction Update 11(5): 495-512.

Meloni, Maurizio. 2016. Political Biology: Science and Social Values in Human Heredity from Eugenics to Epigenetics. Basingstoke, Hampshire; New York: Palgrave Macmillan.

Meloni, Maurizio, Simon Williams and Paul Martin (eds). 2016. Biosocial Matters: Rethinking the Sociology-Biology Relations in the Twenty-First Century. Chichester, West Sussex; Malden, MA: Wiley-Blackwell.

Mol, Annemarie. 2002. the body multiple: ontology in medical practice. Durham; London: Duke University Press.

Mol, Annemarie and John Law. 2004. "Embodied Action, Enacted Bodies: the Example of Hypoglycaemia." Body \& Society 10(2): 43-62.

Nature. 2012. "Life stresses." Nature 490(7419): 143.

Niewöhner, Jörg. 2011. "Epigenetics: Embedded bodies and the molecularisation of biography and milieu." BioSocieties 6(3): 279-98.

Niewöhner, Jörg. 2016. "Co-laborative anthropology: crafting reflexivities experimentally." In The interpretation and analysis of the Ethnological. Towards more transparency in the investigation process, edited by Tytti Steel and Jukka Jouhti (eds), 81-125. Tallinn: Ethnos.

Niewöhner, Jörget al. 2016. "Phenomenography: Relational Investigations into Modes of Being-in-the-World." The Cyprus Review 28(1): 67-84.

Novas, Carlos and Nikolas Rose. 2000. "Genetic risk and the birth of the somatic individual." Economy and Society 29(4): 485-513.

Oyama, Susan, Paul E. Griffiths and Russell D. Gray (eds). 2001. Cycles of Contingency: Developmental Systems and Evolution. Cambridge, Massachusetts: The MIT Press.

Palsson, Gisli. 2016a. Nature, Culture and Society: Anthropological Perspectives on Life. Cambridge: Cambridge University Press.

Palsson, Gisli. 2016b. "Unstable bodies: biosocial perspectives on human variation." The Sociological Review Monographs 64(1): 100-16.

Petryna, Adriana. 2003. Life Exposed: Biological Citizens after Chernobyl. Princeton, New Jersey; Woodstock, Oxfordshire: Princeton University Press.

Rabinow, Paul. 1992. "From sociobiology to biosociality: artificiality and enlightenment." In Incorporations, edited by Jonathan Crary and Sanford Kwinter (eds), 234-52. New York: Urzone.

Rabinow, Paul. 2008. Marking Time: On the Anthropology of the Contemporary. Princeton, New Jersey; Woodstock, Oxfordshire: Princeton University Press.

Rabinow, Paul and Gaymon Bennett. 2012. Designing Human Practices: An Experiment with Synthetic Biology Chicago; London: The University of Chicago Press.

Rabinow, Paulet al. 2008. Designs for an Anthropology of the Contemporary. Durham; London: Duke University Press. 
Raman, Sujatha and Richard Tutton. 2010. "Life, Science, and Biopower." Science Technology \& Human Values 35(5): 711-34.

Rapp, Rayna. 2004. Testing Women, Testing the Fetus: The Social Impact of Amniocentesis in America. Abingdon, Oxon; New York: Routledge.

Rose, Nikolas. 2001. "The Politics of Life Itself." Theory, Culture \& Society 18(6): 1-30.

Rose, Nikolas. 2013. "The Human Sciences in a Biological Age." Theory, Culture \& Society 30(1): 3-34.

Scheper-Hughes, Nancy and Margaret Lock. 1987. "The Mindful Body: A Prolegomenon to Future Work in Medical Anthropology." Medical Anthropology Quarterly 1(1): 6-41.

Söderström, Ola. 2017. "'I Don’t Care About Places': The Whereabouts of Design in Mental Health Care." In Care and Design: Bodies, Buildings, Cities, edited by Charlotte Bates, Rob Imrie and Kim Kullmann (eds), 56-73. Chichester, West Sussex: Jon Wiley \& Sons, Ltd.

Sørensen, Estrid. 2009. The Materiality of Learning: Technology and Knowledge in Educational Practice. Cambridge; New York: Cambridge University Press.

Star, Susan Leigh and James R. Griesemer. 1989. "Institutional Ecology, 'Translations' and Boundary Objects: Amateurs and Professionals in Berkeley's Museum of Vertebrate Zoology, 1907-39." Social Studies of Science 19(3): 387-420.

Thrift, Nigel. 2008. Non-Representational Theory: Space, Politics, Affect. Abingdon, Oxon; New York: Routledge.

Timmermans, Stefan and Steven Haas. 2008. "Towards a sociology of disease." Sociology of Health \& Illness 30(5): 659-76.

Tsing, Anna. 2000. "The Global Situation." Cultural Anthropology 15(3): 327-60.

"What is Anthropology?". 2016. American Anthropological Association. Date Accessed 20/10/2016.

http://www.americananthro.org/AdvanceYourCareer/Content.aspx?ItemNumber=215 0\&navitemNumber $=740$.

Wilson, Edward O. 1975. Sociobiology: The New Synthesis. Cambridge, Massachusetts: Belknap Press of Harvard University Press.

Young, Allan. 1981. "When rational men fall sick: An inquiry into some assumptions made by medical anthropologists." Culture, Medicine and Psychiatry 5(4): 317-35.

Young, Allan. 1982. "The Anthropologies of Illness and Sickness." Annual Review of Anthropology 11(1): 257-85.

Zola, Irving K. 1972. "Medicine as an institution of social control." The Sociological Review 20(4): 487-504.

Patrick Bieler is a $\mathrm{PhD}$ candidate at the Department of European Ethnology at Humboldt-

Universität zu Berlin. His research focuses on the relationship between mental illness, urban environments, psychiatric care and urban planning in Berlin. He is interested in (the combination of) Science and Technology Studies, Urban Anthropology, Medical Anthropology and Anthropology of the Body. 
Jörg Niewöhner is Professor of Social Anthropology at the Department of European Ethnology at Humboldt-Universität zu Berlin. His ethnographic research is primarily concerned with human-environment relations, particularly in the context of life and earth scientific knowledge production. 